\title{
REESCRITAS BRASILEIRAS DOS CONTOS DE PERRAULT: CAMINHOS DIFERENTES EM MONTEIRO LOBATO E MÁRIO LARANJEIRA ${ }^{1}$
}

\section{Anna Olga Prudente de Oliveira}

\section{Introdução}

A Literatura Infantojuvenil (LIJ, doravante), embora tradicionalmente sofra o estigma de ser vista como uma literatura menor, apresenta uma relação com uma das mais antigas e importantes tradições sociais: o contar histórias. Desde a Grécia Antiga a literatura oral tem uma função extremamente relevante na sociedade. Os cantos da Ilíada e da Odisseia, entoados pelos aedos, faziam parte da vida dos helenos, expressando sua forma de lidar com o mundo. Nas mais diversas sociedades, histórias populares, lendas e mitos transmitidos pela oralidade têm exercido influência no modo de vida, nas crenças e nas atitudes humanas. Hoje, no entanto, nas sociedades letradas, a chamada alta literatura pressupõe o leitor individual e silencioso, enquanto o caráter coletivo da literatura oral restringe-se a sociedades ágrafas remotas e a uma peculiaridade que ainda persiste quando entramos na seara da LIJ, uma vez que é muito comum que as histórias infantis sejam transmitidas oralmente para as crianças. Muito presentes nesse contexto de oralidade encontram-se as narrativas populares conhecidas como contos de fadas, histórias em que a realidade convive com o maravilhoso, o mágico, com poderes extra humanos.

Os contos de fadas têm sua origem na tradição oral, remontando a tempos longínquos, em que registros escritos eram escassos e ainda não havia a concepção moderna de autoria. Por conseguinte, essas narrativas foram sofrendo diversas variações conforme o tempo e a cultura em que eram contadas e recontadas, ganhando filiação e forma definidas apenas ao serem fixadas na escrita. A oralidade é nesse caso um fator importante para pensarmos a questão da autoria. Não é possível determinar exatamente quando surgiu uma história como Chapeuzinho Vermelho, por exemplo, nem mesmo se

\footnotetext{
${ }^{1}$ O presente artigo constitui-se de parte de minha dissertação de Mestrado, Chapeuzinho Vermelho: marcas ideológicas e poetológicas de suas escritas e reescritas, defendida em março de 2014 na PUCRio.
} 


\section{OLIVEIRA - Reescritas brasileiras dos contos de Perrault}

houve um único autor para a narrativa. No entanto, contos como esse começaram a receber uma assinatura e uma identidade autoral a partir do século XVII. Os responsáveis por essa fixação tornaram-se então os autores de determinadas versões dos contos, as quais se tornaram as oficiais. Assim, temos Charles Perrault (1628-1703) na França, reconhecido como o primeiro no Ocidente a publicar suas próprias versões para algumas histórias populares na obra Histoires ou Contes du temps passé, avec des Moralités (Histórias ou contos do tempo antigo com moralidades) (1697). Posteriormente, já no século XIX, Hans Christian Andersen (1805-1875) e os irmãos Jacob (1785-1863) e Wilhelm (1786-1859) Grimm dão continuidade ao processo de fixação de narrativas populares. Os contos de fadas propostos por escritores como Perrault, Andersen e os irmãos Grimm tornam-se canônicos na LIJ, exercendo influência na criação e educação de crianças e jovens no mundo todo. Sua configuração como cânone deve-se a suas escritas e, como não poderia deixar de ser, a suas reescritas: traduções e adaptações.

Considerando a importância dessas obras no período de desenvolvimento da LIJ brasileira e observando sua persistência como cânone na LIJ traduzida no Brasil, procuro neste artigo tecer algumas considerações acerca da LIJ e da LIJ traduzida no Brasil, e apresento dois reescritores de grande relevância, tradutores da obra de Charles Perrault: Monteiro Lobato, cujas reescritas inserem-se em um período de desenvolvimento de nossa LIJ nacional, e Mário Laranjeira, que traz ao público leitor contemporâneo uma tradução literária da obra de Perrault.

\section{O universo da literatura infantojuvenil}

\section{LIJ: escritas e reescritas}

A LIJ possui algumas características que precisam ser observadas para que se possa pensar também a tradução desse tipo de literatura. Considera-se LIJ a literatura cujo público alvo são crianças e jovens, cabendo aqui ressaltar que não se caracteriza por obras que crianças e jovens leem, mas sim por obras que são elaboradas e publicadas para — ou especialmente para - esse público (O’Connell, 2006, p. 17). Essa definição que segmenta aprioristicamente a LIJ não deixa de ser questionável, como já observava Cecília Meireles: "Seria mais acertado, talvez, assim classificar 


\section{OLIVEIRA - Reescritas brasileiras dos contos de Perrault}

[como LIJ] o que elas [as crianças] lêem com utilidade e prazer. Não haveria, pois, uma Literatura Infantil 'a priori', mas 'a posteriori'” (Meireles, 1979², apud Mélo \& Machado, 2008, p.10). Sem aprofundar essa discussão conceitual, este artigo parte da definição usual de uma literatura segmentada a partir de sua origem tendo em vista um público alvo específico.

Essa intencionalidade empresta à LIJ muitas vezes um caráter didático ou educativo. Como aponta Nelly Novaes Coelho, "a literatura intencionalmente escrita para as crianças e jovens" começa a desenvolver-se no Brasil vinculada justamente a um projeto educacional, ou "sob a tutela da escola" (Coelho, 2006, p.16-17). No Brasil, especificamente, a LIJ emerge em um momento de transformação social, no processo de urbanização do país, pois

como é à instituição escolar que as sociedades modernas confiam a iniciação da infância tanto em seus valores ideológicos, quanto nas habilidades, técnicas e conhecimentos necessários inclusive à produção de bens culturais, é entre os séculos XIX e XX que se abre espaço, nas letras brasileiras, para um tipo de produção didática e literária dirigida em particular ao público infantil. (Lajolo \& Zilberman, 2007, p.23)

Tendo em vista esse aspecto de sua definição e de seus objetivos, a primeira peculiaridade da LIJ surge então a partir da relação desigual entre autor e seu público preferencial, uma vez que o adulto é o responsável por definir as obras que serão escritas (ou reescritas) e publicadas para as crianças, sendo ele portanto quem tem o poder de decidir sobre aquilo que é ou não apropriado a tal público. Não obstante, é importante notar que, apesar do público alvo ser o infantojuvenil, a LIJ alcança também um público adulto, constituído por familiares e educadores, isto é, aqueles que leem as obras para (ou com) a criança, além de um grupo formado por editores, críticos e pesquisadores. Assim, em uma obra infantil podem ser encontradas certas passagens ou mensagens destinadas a esse público secundário.

A temática e o enredo da LIJ, consonantes à especificidade de seu público alvo prioritário, costumam restringir-se ao que se considera o "universo infantojuvenil". Como crianças e jovens têm uma visão de mundo e conhecimentos limitados a suas

\footnotetext{
${ }^{2}$ Meireles, Cecília. Problemas da literatura infantil. São Paulo: Summus, 1979. $\square$ p.19.
} 


\section{OLIVEIRA - Reescritas brasileiras dos contos de Perrault}

experiências de vida e fases de desenvolvimento, as obras precisam ser adequadas e compreensíveis a tais estágios. Desse modo, na elaboração da literatura voltada para o público infantojuvenil pode ser entrevisto um propósito educacional, com objetivo de instruir e/ou transmitir valores. Assim, a LIJ, além de pertencer ao sistema literário, também transita pelo sistema sócio-educacional, tendo então como funções a educação e socialização de crianças e jovens, e ainda entretenimento e diversão. Como afirma Tiina Puurtinen, "esse duplo caráter afeta a escrita e a tradução de literatura infantil" (Puurtinen, 1995 ${ }^{4}$ apud O'Connell, 2006, p.18).

O caráter didático muitas vezes presente nas obras voltadas para o público infantojuvenil, aliado a restrições de conteúdo e forma (semântica e sintática), tem levado a LIJ a ocupar tradicionalmente um lugar periférico no sistema literário do qual faz parte. Em relação à atividade tradutória, segundo Zohar Shavit (2006), essa posição abre espaço para uma maior liberdade de manipulação textual por parte dos tradutores de obras infantis e juvenis. Shavit entende que, enquanto tradutores contemporâneos de literatura tout court tendem a respeitar o texto em diversos níveis (extensão, aspectos formais, etc.), tradutores de obras voltadas para crianças podem alterar, aumentar ou omitir trechos da obra. No entanto, essas estratégias tradutórias são possíveis (ou aceitáveis) somente se o tradutor estiver considerando um dos dois princípios nos quais a tradução voltada para o público infantojuvenil se baseia: o papel didático desse tipo de literatura e as restrições necessárias considerando-se o nível de conhecimento da criança. São esses dois princípios que possibilitam ao tradutor realizar

uma alteração do texto para torná-lo apropriado e útil à criança, de acordo com o que a sociedade considera (em certo momento histórico) "bom para a criança" em termos educativos; e uma alteração de enredo, caracterização e linguagem para as percepções prevalecentes da sociedade acerca da capacidade de leitura e compreensão da criança. (Shavit, 2006, p.26)

O aspecto didático/educacional assim como a ideia de limitação em termos cognitivos são portanto caraterísticas presentes à concepção de LIJ, as quais

\footnotetext{
${ }^{3}$ Tradução minha, assim como as demais citações extraídas de obras em idioma estrangeiro.

${ }^{4}$ Puurtinen, T. Linguistic Acceptability in Translated Children's Literature. Joensuu: University of Joensuu, 1995. p.17.
} 


\section{OLIVEIRA - Reescritas brasileiras dos contos de Perrault}

consequentemente produzem seus efeitos no campo das reescritas. Cabe aqui ressaltar que muitos textos que são traduzidos com foco no público infantojuvenil nem sempre são voltados ao mesmo tipo de público no sistema literário de origem. Esse fator é importante, pois sempre que uma obra não originalmente direcionada ao público infantojuvenil for reescrita em determinado sistema literário receptor sofrerá coerções relativas às normas de tal sistema. Os responsáveis pela reescrita poderão vir a manipular a obra tendo em vista normas (questões morais, ideológicas, etc.) aceitas e exigidas pelo sistema de literatura infantojuvenil receptor, levando em conta ainda uma adequação ao nível de compreensão da criança (Shavit, 2006, p. 34).

\section{O público infantojuvenil}

Considerando que uma obra é classificada como LIJ tendo em vista o público a que se destina, a existência desse tipo de literatura está vinculada à imagem que crianças e jovens têm em dada sociedade. A LIJ pressupõe a existência de indivíduos cujos interesses, necessidades e características sejam distintos daqueles dos adultos. Se as "crianças" forem vistas como adultos em miniatura não haverá uma preocupação específica quanto a seus gostos, desejos e demandas. Pensar a infância ou a individualização da criança é importante neste caso, pois, à época de Charles Perrault, a ideia de criança inseria-se em um contexto distinto daquilo que se compreende como mundo infantil nos períodos em que as reescritas brasileiras de sua obra são realizadas.

Na Europa ocidental, até a Modernidade, a "criança" fez parte do corpo coletivo da família e devia, por isso, atender às expectativas referentes à manutenção da estrutura familiar, constituída tanto pelos vivos quanto por seus ancestrais. Ao abordar a questão da individualização da criança, em História da vida privada: da Renascença ao Século das Luzes, Jacques Gélis analisa que a criança já nascia "pública", tendo como destino manter o corpo da linhagem. Assim, meninos e meninas tinham uma função social preestabelecida a que precisavam corresponder, e desde cedo eram levados a aprender a desempenhar seus papéis na sociedade (Gélis, 1997, p. 315). As altas taxas de mortalidade infantil e a baixa expectativa de vida também contribuíam para a ausência de uma visão da infância como um período especial e distinto da vida adulta. 


\section{OLIVEIRA - Reescritas brasileiras dos contos de Perrault}

A mudança relativa à percepção da criança como um adulto em miniatura para a visão de um indivíduo com necessidades e interesses próprios faz parte de um processo cultural que ocorre ao longo de um extenso período, que pode ser compreendido do Renascimento ao Iluminismo. Mas se não é possível estabelecer uma cronologia precisa, ao menos na primeira parte do século XVII "já se evidencia um novo sentimento da infância” (Gélis, 1997, p.320). E mesmo no século XVI, é possível observar na iconografia a inserção de crianças retratadas como seres doces, angelicais e inocentes (Shavit, 1999, p.320).

Como analisa Shavit (1999), o desenvolvimento do conceito de infância abrange duas percepções: a primeira refere-se à visão da criança como uma fonte de encantamento para os adultos, fazendo com que nas classes altas as famílias se divertissem com seus filhos em apresentações cujo objetivo era o entretenimento. A segunda percepção baseia-se no entendimento da criança como um ser cuja natureza distinta precisava ser moldada e desenvolvida espiritualmente. Esse aspecto foi se tornando predominante a partir do momento em que adultos fora do ambiente familiar (Igreja, educadores, etc.) passaram a exigir um sistema educacional capaz de disciplinar e educar as crianças de modo apropriado. Assim, livros voltados para as crianças passaram a ser importantes nesse projeto educativo, e essa nova percepção "educacional" por parte da sociedade, diferentemente da percepção do "divertimento" que a precedeu, criou pela primeira vez a necessidade de livros para crianças, e se tornou o quadro de referência no qual os primeiros livros foram escritos para um público alvo especificamente infantil (Shavit, 1999, p.321).

As histórias tradicionais e populares características da oralidade eram até a época de Perrault contadas nos grupos familiares pertencentes às classes mais baixas. Os contos tinham como público alvo todos os membros da família indistintamente. Inserido nesse processo de diferenciação do mundo infantil em relação ao adulto, Perrault recolhe da oralidade diversas histórias e as elabora de modo que pudessem ser lidas e contadas na própria corte francesa. Como os contos folclóricos eram considerados simples e "infantis" pela elite literária, uma forma de fazer com que adentrassem os salões era destinando-os a crianças e jovens. Assim, os contos de Perrault são ambivalentes em relação ao público alvo: embora oficialmente fossem 


\section{OLIVEIRA - Reescritas brasileiras dos contos de Perrault}

destinados ao público jovem também dirigiam-se aos adultos, que começaram a apreciar histórias até então consideradas inferiores. Algumas características presentes no célebre Chapeuzinho Vermelho, por exemplo, corroboram esse entendimento, pois o conto apresenta ambiguidades quanto a sua natureza de conto de fadas, como o fim trágico da personagem (Chapeuzinho é devorada pelo lobo) e a ironia entrevista no poema inserido ao final da história, a moralidade de Perrault. Como aponta Shavit, "enquanto as fórmulas de contos folclóricos designavam o público oficial, a quebra de tais fórmulas — além de um aspecto irônico e satírico dado ao texto - ressaltava o público nãooficial, a elite literária" (Shavit, 1999, p.324).

Se na Modernidade europeia houve um longo processo de individualização da criança, no período em que reescritas dos contos de Perrault e de outros autores estrangeiros começam a ser publicadas no Brasil (a partir do final do século XIX) o entendimento de um mundo infantil com demandas próprias já está consolidado. Desse modo, essas reescritas inserem-se em contextos nos quais se considera que a criança é de fato um indivíduo com necessidades e interesses próprios (ainda que sejam os adultos que definam quais são as necessidades e os interesses infantis). A seguir, comento brevemente o período inicial de desenvolvimento da LIJ brasileira, observando a importância das reescritas nesse momento.

\section{O papel das reescritas no desenvolvimento da LIJ nacional}

No Brasil, o desenvolvimento de uma literatura nacional voltada para o público infantojuvenil tem seus primórdios no século XIX, alcançando um momento marcante e decisivo no início do século XX com Monteiro Lobato (1882-1948). As reescritas exercem um papel relevante para o desenvolvimento dessa literatura incipiente. Como aponta Coelho,

os primeiros livros literários infantis [...] surgiram simultaneamente às formas do ensino que procuravam adequar a cultura brasileira à das nações civilizadas. Tais livros, evidentemente, não eram originais, mas traduções ou adaptações de obras que, na Europa, faziam sucesso entre os pequenos. (Coelho, 2006, p. 18)

Assim, o primeiro livro infantil publicado no Brasil é a coletânea Contos da Carochinha de Alberto Figueiredo Pimentel (1869-1914). Publicada pela Livraria 


\section{OLIVEIRA - Reescritas brasileiras dos contos de Perrault}

Quaresma em $1896^{5}$, a obra é apresentada como um "livro para crianças contendo maravilhosa coleção de contos populares, morais e proveitosos de vários países, traduzidos uns, e outros apanhados da tradição oral" (Pimentel, 1911, capa). Essas reescritas, no entanto, não são relacionadas às suas fontes, pois não há na edição qualquer menção acerca da autoria de cada uma das histórias.

Como um dos precursores da LIJ nacional, Figueiredo Pimentel exerceu um papel relevante trazendo modelos literários da tradição oral e do cânone infantojuvenil estrangeiros para nosso sistema literário, e fazendo com que essas obras servissem ao propósito de formação moral das crianças brasileiras, objetivo expresso no catálogo da editora recomendando o livro, "único que pode guiar as crianças no caminho do bem e da virtude, alegrando e divertindo ao mesmo tempo" (Pimentel, 1911, p. 11).

Entretanto o processo de desenvolvimento de uma literatura voltada para crianças torna-se mais consistente com Monteiro Lobato, que, além de escritor e tradutor, foi editor-proprietário da Companhia Editora Nacional. Alguns anos antes de lançar sua primeira obra infantil, A Menina do Narizinho Arrebitado (1920), o Lobato editor, "já preocupado em inovar e expandir o campo editorial brasileiro, então precaríssimo" (Coelho, 2006, p. 639), adota como estratégia a importação de modelos europeus - contos de fadas, fábulas, etc. — publicando obras voltadas para crianças.

\section{Monteiro Lobato: um projeto nacional}

Além do reconhecimento como tendo sido o criador de uma LIJ brasileira, Monteiro Lobato tem também em sua atuação como tradutor e editor grande importância para o desenvolvimento da literatura nacional. Em 1919, o escritor funda a editora Monteiro Lobato \& Cia., que logo viria a se chamar Companhia Editora Nacional, e "introduz no mercado editorial processos totalmente novos: abre espaço para escritores inéditos; moderniza não só o tratamento gráfico dos livros como também os processos de venda e distribuição comercial" (Coelho, 2006, p. 637). Em seu projeto de desenvolvimento da literatura brasileira, Lobato, enquanto editor, torna-se assim um

\footnotetext{
${ }^{5}$ Há uma edição anterior [1894] que "era uma pequena brochura de 200 páginas, contendo [apenas] quarenta histórias" ("Prefácio da $17^{\mathrm{a}}$ edição". In: Pimentel, 1911, p. ix).
} 


\section{OLIVEIRA - Reescritas brasileiras dos contos de Perrault}

importante agente de patronagem. A patronagem, conforme aponta Lefevere, é o elemento que atua externamente ao sistema literário propriamente dito e pode ser compreendida como "os poderes (pessoas, instituições) que facilitam ou impedem a escrita, a leitura e a reescrita da literatura" (Lefevere, 1985, p. 227).

Lobato trabalhou na tradução de diversos autores de literatura infantil e adulta, considerando que as traduções portuguesas existentes até então, principal meio de acesso do público brasileiro às obras estrangeiras, eram de difícil compreensão. A seu ver, a estrutura e o vocabulário usados eram anacrônicos. Nas cartas que escreve ao amigo e tradutor Godofredo Rangel, publicadas na obra A Barca de Gleyre, Lobato expõe seu pensamento sobre tradução e a linha de sua proposta editorial. Ele trata todas as obras que pretende traduzir de modo semelhante; não as considera "intocáveis", mas sim que deveriam ser traduzidas de modo que o público brasileiro as compreendesse e apreciasse. Desse modo, propõe a Rangel, em carta de 1925:

Os cantos extraídos das peças de Shakespeare vão para que escolhas alguns dos mais interessantes e os traduzas em linguagem bem singela; pretendo fazer de cada canto um livrinho para meninos. [...] Estilo água do pote, hein? E ficas com liberdade de melhorar o original onde entenderes. (Lobato, 1951, v.2, p. 275)

A proposta de Lobato é tornar as obras acessíveis, trazendo-as para uma linguagem que seja facilmente compreendida por todos e que possam, dessa forma, agradar ao público. Contra uma literatura hermética, ele termina a carta em desabafo e palavra de ordem: "Estou a examinar os contos de Grimm dados pelo Garnier. Pobres crianças brasileiras! Que traduções galegais! Temos de refazer tudo isso - abrasileirar a linguagem" (p. 275). O escritor impinge a seu processo tradutório - e também ao dos tradutores de sua editora - uma tarefa de ajudar a constituir e fortalecer a incipiente literatura infantojuvenil brasileira. Mais do que traduzir, "vestir a nacional", um processo no qual não se receava tomar algumas atitudes mais radicais, tais como eliminar partes da obra em questão, como vemos em carta de 1924, (neste trecho, tratando de obra para adultos): 


\section{OLIVEIRA - Reescritas brasileiras dos contos de Perrault}

Não tenhas pressa com o Michelet. Faze-o sossegado. Acho ótimo esse livro, apesar de meio grande. Podemos reduzi-lo com o corte da introdução. E se puseres pedra-hume na tinta, ainda poderás na tradução encurtar umas cinquenta páginas. (p. 270)

Estratégias tradutórias que alteram drasticamente o original (com a supressão de boa parte do texto, por exemplo), de certo modo, realizam uma adaptação desse texto fonte visando um dado sistema literário receptor e determinado público alvo, embora as editoras que publicam tais reescritas possam eventualmente apresentá-las como traduções. Essa questão conceitual relativa ao entendimento de tradução e adaptação é relevante na área das reescritas de LIJ, mas dada a complexidade do tema não cabe aqui um aprofundamento desse aspecto. Não obstante, é importante ressaltar que se os dois conceitos não são indistintos, "não são [tampouco] independentes e livres de qualquer 'transbordamento' entre suas fronteiras" (Amorim, 2005, p. 230).

Em relação a elaboração de obras voltadas para crianças, em carta de 1916, Lobato já refletia sobre sua proposta de abrasileirar as histórias estrangeiras e também sobre o desejo de criar uma nova literatura para esse público. Embora seu primeiro livro infantil tenha sido publicado em 1920, ele já atuava em prol de uma LIJ brasileira em seu trabalho de editor/tradutor.

Ao comentar a recepção das histórias contadas às crianças, Lobato mostra sua percepção de que as moralidades das fábulas não são indicadas a esse público e revela sentir-se livre para realizar as transformações que julgar necessárias a seu projeto, como observamos nesta carta a Rangel:

Ando com várias ideias. Uma: vestir a nacional as velhas fábulas de Esopo e La Fontaine, tudo em prosa e mexendo nas moralidades. Coisa para crianças. Veio-me diante da atenção curiosa com que meus pequenos ouvem as fábulas que Purezinha lhes conta. Guardam-nas de memória e vão recontá-las aos amigos - sem, entretanto, prestarem nenhuma atenção à moralidade, como é natural. A moralidade nos fica no subconsciente para ir se revelando mais tarde, à medida que progredimos em compreensão. Ora, um fabulário nosso, com bichos daqui em vez dos exóticos, se for feito com arte e talento dará coisa preciosa. As fábulas em português que conheço, em geral traduções de La Fontaine, são pequenas moitas de amora do mato - espinhentas e impenetráveis. Que é que nossas crianças podem ler? Não vejo nada. Fábulas assim seriam um começo da literatura que nos falta. Como tenho um certo jeito para impingir gato por lebre, isto é, habilidade por talento, ando com a ideia de iniciar a coisa. É de tal pobreza e tão besta a nossa literatura infantil, que nada acho para a iniciação de meus filhos. (p. 104) 
Assim, inserida nesse contexto de trazer às crianças obras que fossem entendidas e apreciadas, a Companhia Editora Nacional [1934] publica, em tradução de Monteiro Lobato, Contos de Fadas de Perrault (2007a), contendo Capinha Vermelha, As fadas, Barba Azul, O gato de botas, Pele de Asno, A Gata Borralheira, Riquet Topetudo, A bela adormecida e Pequeno Polegar. Apenas Pele de Asno não faz parte da obra Histórias ou contos do tempo antigo com moralidades. Esse conto em verso de Perrault é apresentado em prosa por Lobato.

Sem entrar aqui em uma análise das reescritas propriamente, apenas ressalto uma característica observada em todos os contos reescritos por Lobato: a exclusão da moralidade de Perrault ao final da história. Podemos explicar essa exclusão das moralidades nos contos traduzidos, tendo em vista que, em seu projeto de fomentar uma literatura brasileira para crianças, Lobato não elabora um discurso de respeito ou fidelidade ao original; ao contrário, afirma ser necessário realizar cortes, adaptações e “abrasileirar a linguagem”, como observamos em suas cartas. Um exemplo emblemático da busca por uma aproximação dos textos ao universo e à linguagem infantis pode ser visto ao final do conto Capinha Vermelha, transcrito a seguir:

- C'est pour te manger.Et en disant ces mots, ce méchant Loup se jeta sur le petit chaperon rouge, et la mangea. (Perrault, 2013, p.145)

- É para melhor te comer - e nhoc!, avançou para a menina e a devorou. (Perrault, 2007a, p.10)

Podemos notar que Lobato altera o final, sem mencionar a ideia de "le méchant loup" e inserindo a onomatopeia "nhoc", indicativa do som do lobo devorando a menina rapidamente, o que traz a fala do narrador para uma cena característica da oralidade e de grande apelo ao público infantil.

\section{Mário Laranjeira e a poética da tradução}

Enquanto a reescrita de Monteiro Lobato foi feita em um período de desenvolvimento da LIJ nacional, a tradução da obra de Perrault feita por Mário Laranjeira, já no século XXI, insere-se em um momento em que a LIJ brasileira já está plenamente desenvolvida. Assim, podemos perceber diferenças relevantes quanto aos 


\section{OLIVEIRA - Reescritas brasileiras dos contos de Perrault}

objetivos e resultados das reescritas em questão, evidenciando os diferentes momentos histórico-culturais em que se inserem. Laranjeira traz uma contribuição de grande valor à LIJ ao apresentar uma tradução literária da obra de Perrault, valorizando o texto como literatura e, portanto, não realizando alterações ou cortes significativos.

A tradução de Laranjeira, a obra Contos e fábulas: Charles Perrault, foi publicada em 2007 pela Editora Iluminuras. Trata-se de uma grande coletânea da obra ficcional de Perrault, em que vemos Contos em versos, Histórias ou contos de antigamente com moralidades, O labirinto de Versailles, com 38 fábulas, e Outros contos em prosa e verso. A edição contém ainda um posfácio assinado pelo tradutor e a cronologia de Charles Perrault, paratextos que, devido ao estilo da escrita e ao detalhamento de informações, evidenciam um público alvo adulto. A publicação dessa tradução constitui-se como um marco em termos de divulgação da obra ficcional do autor francês do século XVII para o público leitor brasileiro de hoje, e, nesse caso, o nome do tradutor envolvido no projeto é um fator que denota a relevância desse empreendimento.

Nascido em 1929, o tradutor Mário Laranjeira contribuiu enormemente para o desenvolvimento da área dos Estudos da Tradução no Brasil, tendo se tornado uma das maiores referências brasileiras na área da tradução. Como afirma John Milton, a obra de Laranjeira, Poética da Tradução, resultado de sua tese de doutorado defendida na USP em 1989, "integra as publicações que enxergaram a tradução de um ângulo novo, não vendo a tradução como algo secundário, uma cópia inferior do original, mas sim como uma arte em si, cuja dificuldade exige habilidades e técnicas que são, às vezes, superiores às dos autores do material original" (Milton, 2013, p.13). Laranjeira traduziu importantes escritores e poetas franceses, tais como Gustave Flaubert, Charles Baudelaire e André Gide, tendo sido contemplado com o prêmio Jabuti de tradução, em 1997, por Poetas de França Hoje. É também tradutor de alguns clássicos da prosa ensaística francesa, como, por exemplo, obras de Roland Barthes e Blaise Pascal. Sua tradução de Pensamentos de Pascal recebeu o Prêmio Paulo Rónai da Fundação Biblioteca Nacional e Ministério da Cultura, em 2001. 


\section{OLIVEIRA - Reescritas brasileiras dos contos de Perrault}

Tendo sempre preferido a leitura de poesia à da prosa ${ }^{6}$, Laranjeira desenvolve em Poética da Tradução uma teoria em que aborda justamente a complexidade da tradução poética. Ao considerar as diferenças entre textos informativos, textos em prosa e, finalmente, textos poéticos, o teórico elabora sua tese sobre aquilo que conceitua como significância ${ }^{7}$ " "uma espécie de explosão de sentido". Sua ideia é que

em se tratando de tradução literária e particularmente de tradução de poesia, a tradução não é uma mera troca de significantes com a manutenção do mesmo sentido. A relação significado/significante não é a mesma na prosa científica ou de informação e na poesia. Na poesia essa relação é explodida; o significante não é apenas um veículo, um suporte para o significado, mas adquire certa autonomia. (Faleiros, 2013, p. 120)

Em sua teorização, Laranjeira critica enfaticamente a postura dos que, a priori, afirmam ser impossível a tradução poética (Laranjeira, 2003, p. 23-33). O teórico considera que a visão dualista que opõe objetivamente traduzibilidade à intraduzibilidade ignora a complexidade da atividade tradutória, ao pensar a tradução como uma tarefa de transpor sentidos. Para ele, "a tradução é uma reescritura, noutra língua, de uma leitura do texto. É imprescindível que o sujeito da leitura seja o mesmo da reescritura" (p. 31). Assim, o trabalho do tradutor é ler e (re)produzir sua leitura em outra língua e cultura explorando a poeticidade do texto, sua significância. Entendido como um todo, o texto precisa ser traduzido como um todo, sem uma separação dicotômica entre sentido e significante.

Ao final de seu posfácio à edição de Contos e Fábulas: Charles Perrault, Laranjeira aborda o objetivo de seu trabalho. Em poucas palavras, ele explica como sua teoria é posta em prática; sua busca pela homologia da tradução em relação ao original se dá em vários níveis, considerando-se não somente aspectos semânticos, ou "os conteúdos", mas as diversas características formais (estrutura da escrita em verso ou prosa, ritmos, etc.), como vemos a seguir:

\footnotetext{
${ }^{6}$ Em entrevista a Álvaro Faleiros, Laranjeira comenta: "Desde a minha mais tenra juventude, fui um devorador de poemas. Sempre preferi a leitura de poesia à da prosa" (Faleiros, 2013, p.121).

${ }^{7} \mathrm{Na}$ mesma entrevista, Laranjeira menciona que outros autores já usavam o termo significância, porém não exatamente na mesma acepção desenvolvida por ele. Dentre os que serviram de inspiração ou de base para o que escreveu, ele cita Henri Meschonnic, Roland Barthes, Julia Kristeva, Tzvetan Todorov, entre outros (Faleiros, 2013, p.120-121).
} 


\section{OLIVEIRA - Reescritas brasileiras dos contos de Perrault}

O que caracteriza a tradução que aqui estamos propondo é a tentativa de ficar o mais próximo possível do texto original, seja do ponto de vista dos conteúdos, seja do ponto de vista formal, mantendo em prosa o que estava em prosa e em versos o que estava em versos. Não só, mas, na medida do possível, foram mantidos os mesmos ritmos, as mesmas métricas, as rimas, o mesmo tipo de estrofes etc. É evidente que, em tradução, nunca se pode conseguir identidade com o original; mas tentou-se produzir, em português, um texto tanto quanto possível homólogo ao original de Perrault, isto é, que recupere, com as indispensáveis adaptações para o português, as marcas textuais do original, de modo que provoque no leitor brasileiro um impacto emocional e estético semelhante ao causado pelo texto original no leitor francês. Essa é, ao que nos parece, a função primordial de qualquer tradução literária. (Perrault, 2007b, p. 211)

A ideia de que a reescrita da obra de Perrault é uma tradução literária é central ao pensamento de Laranjeira e estabelece os princípios que norteiam seu trabalho. Como é enfatizado na quarta capa do livro, trata-se de uma "tradução que sem adaptações adocicadas, recupera a fantasia original e seu autêntico sabor popular". Em se tratando de tradução literária, o discurso de Laranjeira é de respeito ao original, no sentido de se buscar, com a tradução, a criação, tanto quanto possível, de um texto homólogo ao texto fonte, recuperando suas "marcas textuais". Pode-se dizer que tal pensamento e perspectiva fornecem as bases teóricas para a área da tradução literária no Brasil hoje. Como sustenta Paulo Henriques Britto, "o tradutor deve produzir um texto que possa ser lido como 'a mesma coisa' que o original”' (Britto, 2012, p. 28). Assim sendo, segundo Britto, o conceito de fidelidade ao texto fonte é de importância central na tradução. É claro que esse conceito pode sofrer mudanças de acordo com épocas ou contextos sociais distintos. Nesse sentido, é preciso "respeitar as convenções do que se entende por tradução, na sociedade e no tempo em que vivemos" (p. 29); o que era considerado uma boa tradução literária há um século não é necessariamente o que se almeja realizar nos dias de hoje. Em nosso sistema literário (tradutório) receptor, a visão atual prevalecente é que a qualidade de uma tradução literária vincula-se ao comprometimento do tradutor com os princípios mencionados na teorização de Laranjeira, isto é, com sua capacidade de trabalhar de modo satisfatório a significância da obra literária ou poética.

Em consonância com seu projeto tradutório, Laranjeira traduz os contos de Perrault sem realizar alterações significativas (diferentemente de Lobato, que exclui as 


\title{
OLIVEIRA - Reescritas brasileiras dos contos de Perrault
}

moralidades dos contos), mantendo prosa e verso de acordo com o original e ainda atendo-se às características rítmicas e mesmo visuais dos poemas inseridos nos contos em prosa com moralidades em verso. Para ilustrar, a seguir, vejamos a moralidade de $A$ Bela Adormecida no bosque, no original e na tradução de Laranjeira, respectivamente:

\author{
Moralité \\ Attendre quelque temps pour avoir un Époux, \\ Riche, bien fait, galant et doux, \\ La chose est assez naturelle; \\ Mais l'attendre cent ans, et toujours en dormant, \\ On ne trouve plus de femelle, \\ Qui dormît si tranquillement.
}

La Fable semble encor vouloir nous faire entendre,

Que souvent de l'Hymen les agréables nouds,

Pour être différés, n'en sont pas moins heureux,

Et qu'on ne perd rien pour attendre ;

Mais le sexe avec tant d'ardeur

Aspire à la foi conjugale,

Que je n'ai pas la force ni le cour,

De lui prêcher cette morale.

(Perrault, 2013, p. 140)

\section{MORAL}

Algum tempo esperar para ter um Esposo

Rico, meigo, galante, gracioso,

Coisa bastante natural;

Mas dormir e esperar cem anos, certamente,

Não se encontra mais essa tal

Mulher que durma assim tranquilamente.

A Fábula parece ainda nos mostrar

Que os laços do Himeneu frequentemente,

Adiados, até ficam mais atraentes,

E não se perde em esperar;

Mas a mulher com tanto ardor

Aspira ao voto conjugal,

Que não tenho coragem nem fervor

Para pregar-lhe esta moral.

(Perrault, 2007b, p. 90)

Sem realizar uma análise micro textual detalhada, o exemplo é trazido aqui apenas para ressaltar a atenção do tradutor em relação às características formais dos poemas de Perrault; vemos que a aparência do texto no papel é mantida, com as mesmas 


\section{OLIVEIRA - Reescritas brasileiras dos contos de Perrault}

duas estrofes (a primeira com 6 versos e a segunda, com 8), os versos longos mais à esquerda e os curtos mais à direita, buscando-se ainda manter alexandrinos e octossílabos e o esquema de rimas do original.

\section{Considerações finais}

As reescritas de Monteiro Lobato e Mário Laranjeira apresentam-se como projetos tradutórios que seguem caminhos diferentes: enquanto Lobato busca criar um repertório que seja próprio às crianças brasileiras, em um movimento de assimilação do estrangeiro a uma cultura nacional, Laranjeira, ao realizar uma tradução literária da obra de Perrault, exerce um papel fundamental para a elevação do status da LIJ, tradicionalmente estigmatizada como uma literatura menor. Como vimos, a intencionalidade e o caráter didático, por vezes moralizante, da LIJ permitem uma "liberdade" maior por parte de tradutores e adaptadores de obras estrangeiras voltadas para crianças. Laranjeira, no entanto, não adentra no caminho da facilitação da linguagem ou da omissão de partes do texto, tratando a obra de Perrault como literatura. Não obstante os diferentes caminhos traçados, de acordo com as concepções de tradução existentes nos dois momentos aqui abordados, tanto a reescrita de Lobato quanto a de Laranjeira atuam no sentido de trazer ao público leitor brasileiro contos que se tornaram clássicos da literatura universal a partir de sua fixação por Charles Perrault na literatura escrita. Essas reescritas exercem assim um papel na (re)criação de imagens de um autor e de sua obra.

\section{Referências}

AMORIM, Lauro Maia. Tradução e adaptação: encruzilhadas da textualidade em Alice no País das Maravilhas, de Lewis Carrol, e Kim, de Rudyard Kipling. São Paulo: UNESP, 2005.

BRITTO, Paulo Henriques. A tradução literária. Rio de Janeiro: Civilização Brasileira, 2012.

COELHO, Nelly Novaes. Dicionário crítico da literatura infantil e juvenil brasileira. 5ed. São Paulo: Companhia Editora Nacional, 2006. 
. Literatura infantil: teoria, análise, didática. $12^{\mathrm{a}}$ impressão. São Paulo: Moderna, 2011.

FALEIROS, Álvaro. Entrevista - Mário Laranjeira. In: (Org.). Mário

Laranjeira: poeta da tradução. São Paulo: Dobra, 2013. p. 117-126.

GÉLIS, Jacques. A individualização da criança. In: História da vida privada, 3: da Renascença ao Século das Luzes. ARIÈS, Philippe; CHARTIER, Roger (Orgs.) Trad. Hildegard Feist. $6^{\text {a }}$. reimpressão. São Paulo: Companhia das Letras, 1997. p. 311-330.

LAJOLO, Marisa; ZILBERMAN, Regina. Literatura Infantil Brasileira: História \& Histórias. 6ed. São Paulo: Ática, 2007.

LARANJEIRA, Mário. Poética da tradução. 2 ed. São Paulo: Edusp, 2003.

LEFEVERE, André. Why Waste Our Time on Rewrites? The Trouble with Interpretation and the Role of Rewriting in an Alternative Paradigm. In: HERMANS, Theo (Ed.). The Manipulation of Literature: Studies in Literary Translation. London \& Sydney: Croom Helm, 1985. p. 215-243.

LOBATO, Monteiro. A Barca de Gleyre. 2 vols. São Paulo: Brasiliense, 1951.

MÉLO, Cristiane Silva; MACHADO, Maria Cristina Gomes. As Contribuições de Cecília Meireles para a Leitura e a Literatura Infantil. Anuário de Literatura, v. 13, n. 2, p. 6-22, 2008.

MILTON, John. Poética da tradução, de Mário Laranjeira. In: FALEIROS, Álvaro (Org.). Mário Laranjeira: poeta da tradução. São Paulo: Dobra, 2013. p. 13-17.

O'CONNELL, Eithne. “Translating for Children”. In: LATHEY, Gillian (Ed.). The

Translation of Children's Literature: A Reader. UK: Multilingual Matters, 2006. p. 15-24.

PERRAULT, Charles. Contos de fadas. Tradução: Monteiro Lobato. 2 ed. São Paulo: Companhia Editora Nacional, 2007a.

. Contos e fábulas: Charles Perrault. Tradução e posfácio: Mário Laranjeira.

São Paulo: Iluminuras, 2007b.

Contes; édition critique de Jean-Pierre Collinet. Coleção Folio Classique. Paris: Gallimard, 2013[1981]. 
PIMENTEL, Figueiredo. Contos da Carochinha. Rio de Janeiro: Quaresma \& CA Livreiros Editores, 1911.

SHAVIT, Zohar. Translation of Children's Literature. In: LATHEY, Gillian. The Translation of Children's Literature: A Reader. UK: Multilingual Matters, 2006. p. 25-40.

. The Concept of Childhood and Children's Folktales: Test Case - "Little Red Riding Hood". In: TATAR, Maria (Ed.). The Classic Fairy Tales. New York, London: Norton, 1999. p. 317-332. 